Original article

\title{
Ovarian activation in Melipona quadrifasciata queens triggered by mating plug stimulation (Hymenoptera, Apidae)
}

\author{
Gabriel A.R. Melo ${ }^{\mathrm{a} *}$, Maria Luisa T. BusCHINI ${ }^{\mathrm{b}}$, \\ Lucio A.O. CAMPOS ${ }^{\mathrm{c}}$ \\ ${ }^{a}$ Departamento de Zoologia, Universidade Federal do Paraná, Cx. Postal 19020, 81531-990, \\ Curitiba, PR, Brazil \\ b Departamento de Biologia, Universidade Estadual do Centro-Oeste, Rua Presidente Zacarias \\ 875, 85015-430, Guarapuava, PR, Brazil \\ c Departamento de Biologia Geral, Universidade Federal de Viçosa, 36570-001, \\ Viçosa, MG, Brazil
}

(Received 20 April 2000; revised 22 March 2001; accepted 9 April 2001)

\begin{abstract}
The effect of the detached male genital capsule on ovarian activation in queens of the stingless bee Melipona quadrifasciata, and the amount of time the genital capsule remains attached to the queen genital chamber after mating, were investigated. Twenty-four controlled matings were carried out and the male capsules were manually removed at preset time intervals. The results indicate that the experimental removal of the mating plug on the first three days after mating inhibits ovarian activation or strongly decreases the chances that it will happen. After this period it would not affect ovarian activation, despite continuing to be attached to the queen for a few more days. It is suggested that the male genital capsule provides mechanical stimulation only.
\end{abstract}

Hymenoptera / Melipona quadrifasciata / stingless bees / ovarian development

\section{INTRODUCTION}

In insects, several internal and external factors influence the total egg production by females. Among such factors, mating can vary from causing a slight acceleration in oogenesis, to being the sole factor responsible for the onset of egg maturation in these animals (Engelmann, 1970; Wheeler, 1996).

Nothing is known about the factors that trigger ovarian activation in stingless bees.

* Correspondence and reprints

E-mail: garmelo @ bio.ufpr.br 
In their close relatives of the genus Apis, unmated queens mature their ovaries very slowly compared to mated queens; however, virgin queens introduced into orphaned colonies after double $\mathrm{CO}_{2}$ narcosis develop their ovaries as fast as mated queens (Engels et al., 1976). Queens in the stingless bee Melipona quadrifasciata are born with small, inactive ovaries. Virgin queens kept with food and workers do not mature their ovaries, and eventually die or are killed by the workers in a few weeks; also, differently from Apis, they do not respond to $\mathrm{CO}_{2}$ treatment (Melo, unpublished data).

In M. quadrifasciata, the queens mate only once and during mating the male loses his genitalia, leaving it attached to the queen's genital chamber (Kerr and Krause, 1950; Kerr et al., 1962; Silva et al., 1972). According to Silva et al. (1972), the detached male genitalia are removed by the queen herself soon after returning from the mating flight. Single mating seems to be the rule in stingless bees (Peters et al., 1999). [Evidence for multiple mating found by Paxton et al. (1999) might be due to mating with physogastric queens (see Campos and Melo, 1990) during artificial disturbance of colonies]. Also, judging from the relatively uniform morphology of the male genitalia in stingless bees (Michener, 1990), loss of the male genitalia during mating is probably universal among them.

The role of the detached male genitalia in stimulating ovarian activation in recently mated queens of $M$. quadrifasciata was first noticed in an earlier unintentional experiment when controlled matings were being carried out for a genetic study: two out of four queens had the male genital capsule manually removed one day after mating; these two queens showed no ovarian activation 30 days after mating, while the two unmanipulated queens had already matured their ovaries and started oviposition. This unexpected result gave us the impetus to carry out further investigations.

\section{MATERIALS AND METHODS}

The M. quadrifasciata bees used in our experiments were obtained from colonies maintained in hives at the Federal University of Viçosa, Minas Gerais State, Brazil. The controlled matings and the establishment of the new colonies (newly mated queen plus workers) were carried out accordingly to the technique described by Camargo (1972a, 1976). We took combs with brood close to emergence to obtain virgin queens and workers, each comb being kept separately in a Petri dish. Mature males were collected inside the hives and were also kept in Petri dishes until mating. All the Petri dishes had a circular filter paper covering the bottom and a small container with diluted honey.

The virgin queens were 1-3 days old and the matings took place in a small wooden box $(11 \times 8 \times 3 \mathrm{~cm})$ covered with a transparent plastic lid. The bees were mated one pair at a time. After mating, the queens were observed under a dissecting microscope to check the position of the male genitalia in their genital chamber and were marked with a paint spot in the mesoscutum. Each mated queen was transferred to a Petri dish with 20 newly born workers plus food (honey and pollen from $M$. quadrifasciata colonies or honeybee pollen fermented with $M$. quadrifasciata pollen seed). Every day, 15 newly born workers were added to the new colonies. Eight days after mating, the queens and workers were transferred to a wood box $(20 \times 20 \times 6 \mathrm{~cm})$ supplied with food and soft cerumen. All the experimental material (combs, males and new colonies) was kept in a incubator under $28^{\circ} \mathrm{C}$.

The different treatments consisted of removing the mating plug (detached male genital capsule) from the queen genital chamber at different intervals after the mating. The time intervals used are shown in Table I (treatments 1 to 7). In treatments 6 and 7 , the queens were manipulated 10 and 13 days, respectively, after mating. The experimental queens were taken from the 
Table I. Influence of the experimental removal of the mating plug on ovarian activation in queens of Melipona quadrifasciata. Treatment: time interval between mating and removal of male genitalia; $\mathrm{n}$ : number of queens submitted to each treatment.

\begin{tabular}{cccccc}
\hline Treatment & $\begin{array}{c}\text { Time between } \\
\text { mating and removal } \\
\text { of male genitalia }\end{array}$ & $n$ & $\begin{array}{c}\text { Number of queens } \\
\text { that did not show } \\
\text { ovarian activation }\end{array}$ & $\begin{array}{c}\text { Number of queens } \\
\text { that showed } \\
\text { ovarian activation }\end{array}$ & $\begin{array}{c}\text { Number of queens } \\
\text { that died before } \\
\text { the mean period for } \\
\text { the onset of oviposition }\end{array}$ \\
\hline 1 & 5 hours & 2 & 2 & - & - \\
2 & 1 day & 2 & - & - & 2 \\
3 & 3 days & 5 & 4 & 1 & - \\
4 & 5 days & 4 & - & 3 & 1 \\
5 & 6 days & 3 & 1 & 1 & 1 \\
6 & unknown $^{\dagger}$ & 2 & - & 2 & - \\
7 & unknown $^{\dagger}$ & 2 & - & 2 & - \\
8 & Control $^{*}$ & 4 & - & 4 & 4 \\
\hline Total & & 24 & 7 & 13 & - \\
\hline
\end{tabular}

Queens in treatments 6 and 7 had no attached male genitalia when examined 10 and 13 days, respectively, after mating; * non-manipulated queens.

Petri dish (or from the wood box for treatments 6 and 7) and had the male genitalia removed, if present, with the aid of a very fine forceps under a dissecting microscope. The queens were returned to their respective colonies immediately after the manipulation. Queens in treatments 3 to 7 were held with the help of a cotton ball to prevent direct contact with fingers, since workers older than 2 to 3 days can discriminate and kill non-physogastric queens that have been touched with bare fingers (Melo, unpublished data). The control treatment consisted of queens not manipulated after mating. The queens were followed for at least 25 days to observe their ovarian maturation and to determine when they initiated egg laying. Ovarian maturation was evaluated through increase in the volume of the metasoma. After this period, some of the queens had the number of spermatozoa in their spermatheca counted, using the technique described by Camargo (1972b).

\section{RESULTS}

All the queens from treatments 1 to $5 \mathrm{had}$ the male genitalia attached to their genital chamber when they were manipulated. Queens from treatments 6 and 7 had no male genitalia when examined, indicating that the male genitalia was lost or removed between six and 10 days after mating, under our experimental conditions.

The results of the different treatments are summarized in Table I. In treatment 1, the two queens were observed for a total period of, respectively, 25 and 29 days, and did not exhibit any activation of their ovaries. Queens in treatment 2 died three and eight days after the mating, without any sign of ovarian activation. In treatment 3 , only one queen fully developed her ovaries, while the four remaining queens still had undeveloped ovaries $21(n=2), 24$ and 30 days after mating, respectively. One out of three queens in treatment 5 showed ovarian development; the other two died eight and 18 days 
Table II. Time, in days, elapsed between mating and onset of oviposition in queens of Melipona quadrifasciata.

\begin{tabular}{ccc}
\hline Treatment & $n$ & Time (in days) \\
\hline 3 & 1 & 15 \\
4 & 3 & 15,16 and 20 \\
5 & 1 & 15 \\
6 & 2 & 16 and 21 \\
7 & 2 & 15 and 16 \\
8 & 4 & $12,15,15$ and 19 \\
\hline Total & 13 & mean $=16.2 ; \mathrm{sd}=2.44$ \\
\hline
\end{tabular}

after mating, respectively. Finally, all the queens in treatment 6, 7 and 8 (control) fully developed their ovaries and began oviposition 16.2 days, on average, after mating (Tab. II).

The sperm counts revealed that two control queens had 682500 and 885000 spermatozoa, respectively, in their spermatheca. They were physogastric and had just begun oviposition. Two other queens, one from treatment 1 and one from treatment 3 , had 990000 and 1027500 spermatozoa, respectively. Both queens had small, undeveloped ovaries.

\section{DISCUSSION}

Although the sample size is small for most treatments, the results indicate that the experimental removal of the mating plug on the first days after mating inhibits ovarian activation or strongly decreases the chances that it will happen. The mating plug seems to exert a strong influence on the first days (from one to three days) and after this period it does not affect ovarian activation, despite continuing to be attached to the queen for a few more days. If the data presented in Table I is collapsed into only two treatment categories - (1) capsule removed before day 4 and (2) capsule removed after day 4 - the frequency in which the queens had their ovaries activated differs significantly between these two categories when applying a contingency test $(G=9.027, p<0.01$; cases involving premature death excluded).

The negative result obtained in treatment 5 might be related to another experimental effect: an increase in mortality rate among the manipulated queens. Although it was considered a negative result, since the queen died 18 days after mating without showing any significant ovarian activation, her relatively early death might have been caused by experimental manipulation. The two queens of treatment 2 , one in treatment 4 , and one in treatment 5 died before the average interval taken by the control queens to mature their ovaries and start oviposition. They died between 3 and 8 days after mating and had no signs of ovarian activation. Melo and Santana (unpublished data) also found a higher mortality rate in an experiment where the queens had the mating plug removed a few hours after mating and were put to remate after that. As the tip of the genitalia valves are pulled deeply into the membrane of the queen's genital chamber, the forced removal of the genitalia may cause the accidental perforation of the membrane and indirectly death of the queen. Membrane perforations caused by the valves seem to be involved in the death of physogastric queens of M. quadrifasciata when mated experimentally with several males (Campos and Melo, 1990).

The genital capsule of M. quadrifasciata males seems to provide only mechanical stimulation. The pressure exerted by the genitalia valves onto the queen's genital chamber walls could provide the necessary stimulus, via nervous system, to activate production of juvenile hormone by the corpora allata, as has been demonstrated in other insects. In Diploptera cockroaches, for example, egg maturation is mechanically stimulated through copulation and virgin females develop their ovaries when artificial spermatophores are inserted into their 
bursa copulatrix; ovarian activation, however, does not occur when the ventral nerve chord is severed prior to mating (Engelmann, 1959).

Seminal products transferred during mating have been implicated in triggering ovarian maturation in a number of insects (Eberhard, 1996). We do not believe, however, that such substances are involved in ovarian activation in queens of $M$. quadrifasciata. Although the seminal vesicles are transferred together with the male genital capsule during mating (Kerr and Krause, 1950; Camargo, 1972a), complete transfer of male products to the female reproductive tract apparently takes less than one hour (the results from the sperm counts indicate that the experimental treatments did not interfere with sperm transfer). Also, the soft tissues associated with the male capsule dry out in a few hours and it seems unlikely that the capsule would continue to release any significant amount of a substance capable of interfering with the queen's physiology.

Silva et al. (1972) and Camargo (1972a) reported that queens of Melipona quadrifasciata and $M$. quinquefasciata get rid of the male genitalia soon after returning from the mating flight. Our results do not support their observations, since under our experimental conditions the male genital capsule remained attached to the queen for at least six days. Judging from the description given in Silva et al. (1972), these authors might have taken the elimination of the whitish soft tissues attached to the male genital capsule as evidence for removal of the capsule itself.

The findings reported here have implications for the development of techniques of artificial insemination in Melipona. Although a way of triggering ovarian activation in Melipona queens without involving mating might be found in the future, one alternative way to carry out artificial inseminations in these bees would be to mate queens with males made sterile by high dosages of radiation (60 to $80 \mathrm{krad}$ ) and then artificially inseminate them after they become physogastric. Matings with radiation-sterile males, followed by normal ovarian maturation and oviposition, have been successfully carried out in $M$. quadrifasciata (Melo, unpublished data). Also, Campos and Melo (1990) have shown that egg-laying queens in $M$. quadrifasciata remain physiologically capable of receiving and storing more spermatozoa.

Résumé - L'activation ovarienne des reines de Melipona quadrifasciata (Hymenoptera, Apidae) déclenchée par la stimulation du bouchon d'accouplement. On ne connaît rien des facteurs qui déclenchent l'activation ovarienne chez les abeilles sans aiguillon. Lors d'une expérience précédente, dans laquelle on pratiquait des accouplements contrôlés pour une étude de génétique, on a pour la première fois remarqué le rôle du bouchon d'accouplement (capsule génitale mâle qui se détache) dans la stimulation de l'activation ovarienne chez des reines de $M$. quadrifasciata récemment fécondées : on a retiré manuellement la capsule génitale mâle à deux des quatre reines un jour après l'accouplement ; ces reines n'ont présenté aucune activation ovarienne, alors que les ovaires des deux reines non manipulées avaient mûri et que celles-ci s'étaient mises à pondre. Ce résultat inattendu nous a décidé à faire d'autres expériences. Dans l'étude présentée ici, 24 accouplements contrôlés ont été effectués selon la technique décrite par Camargo (1972a, 1976) et les différents traitements ont consisté à retirer le bouchon d'accouplement de la chambre génitale de la reine à divers intervalles de temps après l'accouplement (traitements 1 à 7, cf. Tab. I). Les résultats montrent que le retrait manuel du bouchon d'accouplement durant les trois premiers jours après l'accouplement inhibe l'activation ovarienne ou diminue fortement les chances qu'elle ait lieu (Tab. I). Après cette période, le bouchon n'affecterait pas l'activation ovarienne même s'il reste encore 
attaché quelques jours. Les produits séminaux transférés au cours de l'accouplement sont impliqués dans le déclenchement de l'activation ovarienne chez un certain nombre d'insectes (Eberhard, 1996). Nous ne pensons pas que de telles substances soient impliquées dans l'activation ovarienne des reines de $M$. quadrifasciata. La capsule génitale des mâles de $M$. quadrifasciata semble ne fournir qu'une stimulation mécanique. La pression exercée par les valves des génitalia sur les parois de la chambre génitale de la reine pourrait fournir le stimulus nécessaire, via le système nerveux, pour activer la production d'hormone juvénile par les corpora allata, comme cela l'a été montré chez d'autres insectes. Nos résultats ne confortent pas les observations de Silva et al. (1972) et de Camargo (1972a), selon lesquelles les reines de M. quadrifasciata et $M$. quinquefasciata se débarrassent des génitalia mâles peu de temps après être rentrées de leur vol de fécondation, puisque dans nos conditions expérimentales la capsule génitale mâle est restée attachée à la reine pendant au moins six jours.

Melipona quadrifasciata / abeille sans aiguillon / développement ovarien

Zusammenfassung - Reizung durch den Begattungspfropf bewirkt eine Aktivierung der Ovarien bei Melipona quadrifasciata Königinnen (Hymenoptera, Apidae). Über Faktoren, die eine Reifung der Eierstöcke stimulieren, ist bei Stachellosen Bienen nichts bekannt. Die Funktion von Begattungspfropf bei der Stimulation kurz nach der Paarung von Melipona quadrifasciata Königinnen wurde zufällig bei anderen Experimenten beobachtet, die auf Grund genetischer Studien gemacht wurden: Bei 2 von 4 Königinnen wurde die männliche Genitalkapsel einen Tag nach der Paarung mit der Hand entfernt. Bei diesen beiden Königinnen hatten sich die Ovarien 30 Tage nach der Paarung nicht entwickelt, während die nicht manipulierten Königinnen entwickelte Ovarien hatten und bereits Eier legten. Diese unerwartete Beobachtung veranlasste uns weitere Versuche zu machen. Es wurden 24 kontrollierte Paarungen nach der Methode von Camargo (1972a, 1976) durchgeführt. In verschiedenen zeitlichen Abständen nach der Paarung wurde der Begattungspfropf (abgetrennte Genitalkapsel der Männchen) aus den Genitalkammern der Königinnen entfernt. Die Zeitabstände sind in Tabelle I (Versuch 1-7) angegeben. Nach diesen Ergebnissen verhindert die Entfernung des Begattungspfropfs innerhalb der ersten 3 Tage die Reifung der Eierstöcke oder mindert zumindest die Chance, dass die Reifung einsetzt (Tab. I). Nach dieser Zeitperiode scheint er keinen Einfluss mehr zu haben, obwohl normalerweise der Pfropf noch mehrere Tage in der Königin verbleibt. Substanzen aus dem Ejakulat sollen bei vielen Insekten die Reifung der Ovarien auslösen (Eberhard, 1966). Wir glauben nicht, dass solche Substanzen bei der Ovaraktivierung von $M$. quadrifasciata Königinnen eine Rolle spielen. Von der Genitalkapsel der M. quadrifasciata Männchen scheint nur eine mechanische Stimulation auszugehen. Der Druck, der von den Genitalklappen auf die Wände der Geschlechtskammer der Königinnen ausgeht, könnte den notwendigen Stimulus bilden, der über das Nervensystem die Produktion von Juvenilhormon bei den Corpora allata aktiviert, wie bei anderen Insekten gezeigt wurde. Unsere Ergebnisse unterstützen die Beobachtungen von Silva et al. (1972) und Camargo (1972a) nicht, nach denen Königinnen von $M$. quadrifasciata und $M$. quinquefasciata die Genitalkapsel der Männchen kurz nach der Rückkehr vom Hochzeitsflug abstreifen, weil unter unseren Bedingungen dieser Pfropf für mindestens 6 Tage in der Königin verblieb.

Hymenoptera / Melipona quadrifasciata / Stachellose Bienen / Ovarreifung 


\section{REFERENCES}

Camargo C.A. (1972a) Mating of the social bee Melipona quadrifasciata under controlled conditions (Hymenoptera, Apidae), J. Kans. Entomol. Soc. 45, 520-523.

Camargo C.A. (1972b) Aspectos da reprodução dos Apídeos sociais, Master Degree thesis, Universi dade de São Paulo, Ribeirão Preto, Brazil.

Camargo C.A. (1976) Determinação do sexo e controle de reprodução em Melipona quadrifasciata Lep. (Hymenoptera, Apidae), Ph.D. dissertation, Universidade de São Paulo, Ribeirão Preto, Brazil.

Campos L.A.O., Melo G.A.R. (1990) Physogastricqueen mating in Melipona quadrifasciata Lep. (Hymenoptera, Apidae), Rev. Bras. Gen. 13, 491-500.

Eberhard W.G. (1996) Female Control: Sexual Selection by Cryptic Female Choice, Princeton University Press, Princeton.

Engelmann F. (1959) The control of reproduction in Diploptera punctata (Blattaria), Biol. Bull. 116 , 406-419.

Engelmann F. (1970) The Physiology of Insect Reproduction, Pergamon Press, New York.
Engels W., Gonçalves L.S., Engels E. (1976) Effects of carbon dioxide on vitellogenin metabolism in unmated queen honeybees, J. Apic. Res. 15, 3-10.

Kerr W.E., Krause W. (1950) Contribuição para o conhecimento da bionomia dos Meliponini. Fecundação da rainha em Melipona quadrifasciata Lep. (Hymenop.-Apoidea), Dusenia 1, 275-278.

Kerr W.E., Zucchi R., Nakadaira J.T., Butolo J.E. (1962) Reproduction in the social bees (Hymenoptera: Apidae), J. New York Entomol. Soc. 70, 265-276.

Michener C.D. (1990) Classification of the Apidae, Univ. Kans. Sci. Bull. 54, 75-164.

Paxton R.J., Weißschuh N., Engels W., Hartfelder K. (1999) Not only single mating in stingless bees, Naturwissenschaften 86, 143-146.

Peters J.M., Queller D.C., Imperatriz-Fonseca V.L., Roubik D.W., Strassmann J.E. (1999) Mate number, kin selection and social conflicts in stingless bees and honeybees, Proc. Roy. Soc. London B 266 , 379-384.

Silva D.L.N., Zucchi R., Kerr W.E. (1972) Biological and behavioural aspects of the reproduction in some species of Melipona (Hymenoptera, Apidae, Meliponinae), Anim. Behav. 20, 123-132.

Wheeler D. (1996) The role of nourishment in oogenesis, Annu. Rev. Entomol. 41, 407-431. 